Original Article

\title{
Comprehensive Analysis of Gene Expression Associated with Caries Susceptibility in Chromosome 2-substituted Mice
}

\author{
Terukazu Kokubun, ${ }^{1}$ and Kunihiko Shimizu² \\ ${ }^{1}$ Nihon University Graduate School of Dentistry at Matsudo, Pediatric Dentistry, Matsudo, Chiba 271-8587, Japan \\ ${ }^{2}$ Department of Pediatric Dentistry, Nihon University School of Dentistry at Matsudo, Matsudo, Chiba 271-8587, Japan
}

\section{Article History}

Received 6 December 2012

Accepted 7 December 2012
Keywords :

dental caries susceptibility, consomic mice, genechip microarray, chromosome2

\begin{abstract}
In this study, in order to clarify the host genetic factors that influence dental caries susceptibility, we examined the role of host genetic factors by comparing whole genome expression and salivary protein levels using C57BL/6 (B6) mice, which showed high dental caries susceptibility, and $\mathrm{C} 3 \mathrm{H}$ and $\mathrm{B} 6-\mathrm{Chr} 2^{\mathrm{C} 3 \mathrm{H}}$ mice, which show low dental caries susceptibility.

We analyzed gene expression in the submandibular gland by genechip microarray using submandibular glands from $\mathrm{B} 6, \mathrm{C} 3 \mathrm{H}$ and $\mathrm{B} 6-\mathrm{Chr} 2^{\mathrm{C} 3 \mathrm{H}}$ mice. Two genes that showed the top expression in each category among the 3 strains were analyzed by reverse transcription polymerase chain reaction (RT-PCR) and quantitative Real-Time PCR analyses. We also analyzed saliva protein concentration by the Bradford method.

On microarray analysis, the Tmem $87 A$ and Capn3 genes showed the greatest differences in gene expression among the 3 strains. These genes were confirmed by RT-PCR and quantitative Real-Time PCR, and protein concentrations in $\mathrm{C} 3 \mathrm{H}, \mathrm{B} 6-\mathrm{Chr} 2^{\mathrm{C} 3 \mathrm{H}}$ and $\mathrm{B} 6$ were $0.210 \mu \mathrm{g} / \mathrm{ml}, 0.177 \mu \mathrm{g} / \mathrm{ml}$ and $0.217 \mu \mathrm{g} / \mathrm{ml}$, respectively. Protein concentrations in $\mathrm{B} 6-\mathrm{Chr} 2^{\mathrm{C} 3 \mathrm{H}}$ were significantly lower than in $\mathrm{B} 6$ and $\mathrm{C} 3 \mathrm{H}$. Thus, Tmem87A and Capn 3 may be related to differences in caries susceptibility observed with the Substituted of chromosome 2 in mice. Moreover, protein levels in saliva do not affect caries susceptibility in 3 strains. This suggests that differences in caries sensitivity of $\mathrm{B} 6, \mathrm{C} 3 \mathrm{H}$ and $\mathrm{B} 6-\mathrm{Chr} 2^{\mathrm{C} 3 \mathrm{H}}$ are related to differences in water permeability in the salivary glands.
\end{abstract}

\section{Introduction}

Dental caries is one of the most prevalent chronic diseases in pediatric dental patients and affects their growth and well-being. Dental caries is a multifactorial disease widely acknowledged to be caused by a combination of environmental and behavioral factors, and genetic predispositions. The environmental risk factors for dental caries have been studied for decades, and include dietary behaviors, bacterial flora, transmission of bacteria among hosts, hygiene, socioeconomic status and access to oral health care. However, little is known about the relationship between host genetic background and the progress of dental caries

Correspondence to :

Kunihiko Shimizu

E-mail : shimizu.kunihiko@nihon-u.ac.jp
(1-3). It is important to identify host genetic factors controlling caries susceptibility, and to clarify the host defense mechanisms influencing caries development.

In our previous study, we reported that various inbred mouse strains developed dental caries after infection with Streptococcus mutans (S.mutans), and high sucrose consumption, and it was noted that the mice could be divided into two groups, corresponding to high and low caries susceptibility; the C57BL/6 strain (B6) showed high susceptibility and the $\mathrm{C} 3 \mathrm{H}$ strain (C3H) showed low susceptibility (4-7). As a result of quantitative trait locus (QTL) analysis, four QTLs were detected on chromosomes 1, 2, 7 and 8. In particular, the QTL on chromosome 2 showed a strong relationship with dental caries susceptibility $(8,9)$. For the elucidation of the causative genes for 
dental caries susceptibility, we established chromosome-substitution mice, known as consomic mice $\left(\mathrm{B} 6-\mathrm{Chr} 2^{\mathrm{C} 3 \mathrm{H}}\right)$, in which all chromosomes except chromosome 2 were derived from B6 (10). On caries induction in $\mathrm{B} 6-\mathrm{Chr} 2^{\mathrm{C} 3 \mathrm{H}}$ infected with S.mutans JC-2 (serotype c), the caries score for $\mathrm{B} 6-\mathrm{Chr} 2^{\mathrm{C} 3 \mathrm{H}}$ was significantly lower than that in B6, and did not differ significantly from that in $\mathrm{C} 3 \mathrm{H}$. Salivary flow volume in $\mathrm{B} 6-\mathrm{Chr} 2^{\mathrm{C} 3 \mathrm{H}}$ was also greater than in $\mathrm{B} 6$ and was significantly less than in $\mathrm{C} 3 \mathrm{H}(11)$.

B6-Chr2 ${ }^{\mathrm{C} 3 \mathrm{H}}$ strain showed low dental caries susceptibility and the 3 mouse strains showed differences in salivary flow volume. However, no studies have been performed to investigate the host genetic factors that influence dental caries susceptibility using $\mathrm{B} 6-\mathrm{Chr} 2^{\mathrm{C} 3 \mathrm{H}}$.

In this study, we investigated gene expression in the submandibular glands of 3 mouse strains that show differences in caries susceptibility. To clarify the host genetic factors that most strongly influence dental caries susceptibility, we comprehensively compared the whole genome expression in the submandibular gland. In addition, as salivary protein influences caries susceptibility, we also examined salivary protein levels in the 3 mouse strains.

\section{Materials and Methods}

Mice

$\mathrm{C} 57 \mathrm{BL} / 6 \mathrm{CrSlc}(\mathrm{B} 6)$ and $\mathrm{C} 3 \mathrm{H} / \mathrm{HeSlc}(\mathrm{C} 3 \mathrm{H})$ mice, and consomic mice $\left(\mathrm{B} 6-\mathrm{Chr} 2^{\mathrm{C} 3 \mathrm{H}}\right)$ were used in this study. Twenty-day-old B6 and C3H mice were purchased from Sankyo Lab Service Co. (Tokyo, Japan), and B6-Chr2 ${ }^{\mathrm{C} 3 \mathrm{H}}$ mice were maintained in our laboratory. All mice were kept in clean racks at room temperature $\left(25 \pm 1^{\circ} \mathrm{C}\right)$, with a relative humidity of $55 \pm 5 \%$, and a 12-hour light/dark cycle. Mice were fed ad libitum on a commercial diet (MR Breeder; Nihon Nohsan Co., Kagawa, Japan), and were provided pure bottled water. The animal-use protocols of this study were reviewed and approved by the Nihon University Institutional Review Board (ECA 08-0012).

\section{RNA isolation and microarray analysis}

For gene expression analysis, submandibular glands were dissected from the 3 mouse strains at 49 days of age. Total RNA was individually extracted from submandibular glands using FastRNA Pro Green Kit (MP Biomedicals, Santa Ana, $\mathrm{CA}$ ), according to the manufacturer's instructions. The concentration and purity of the RNA were determined spectrophotometrically. RNA samples were analyzed on 1\% agarose gels by electrophoresis, followed by staining with ethidium bromide in order to verify the integrity of $18 \mathrm{~S}$ and $28 \mathrm{~S}$ ribosomal RNA. First-strand cDNA was synthesized from 500ng of total RNA using a Gene Chip 3'IVT Express Kit (Affymetrix Inc. Santa Clara, CA). Second-strand cDNA was synthesized from $10 \mu \mathrm{L}$ of first-strand cDNA, and biotin-labeled amplified RNA (aRNA) was transcribed from cDNA. aRNA (15 $\mu \mathrm{g})$ was fragmented to obtain optimal array sensitivity and minimize the required amount of magnesium. Fragmented aRNA was hybridized to a Mouse Genome 430 2.0 Array (Affymetrix Inc.) for 16 hours at $45^{\circ} \mathrm{C}$. The array was washed and stained with streptavidin-phycoerythrin using a Fluidics Station (Affymetrix Inc.). Digital images were obtained using a Gene Array Scanner (Affymetrix Inc.).

\section{Statistical analysis of microarray data}

The resulting data from the 3 mouse strains were analyzed using Affymetrix Expression Console Software (version 1.1, Affymetrix) and Ingenuity Pathways Analysis (IPA) (12). Affymetrix Microarray suite 5.0 (Mas5) was used to obtain the generated signal values and detection calls (Present (P), Absent (A) or Marginal (M)), and the data were exported for further analysis. On analysis of gene expression data, we divided data into two categories. Category 1 included present calls in $\mathrm{C} 3 \mathrm{H}$ and $\mathrm{B} 6-\mathrm{Chr} 2^{\mathrm{C} 3 \mathrm{H}}$ and absent calls in $\mathrm{B} 6$, while signal intensity of $\mathrm{C} 3 \mathrm{H}$ and B6-Chr2 ${ }^{\mathrm{C} 3 \mathrm{H}}$ was more than 300 and existed on chromosome 2. Category 2 included present calls in the 3 mouse strains and gene expression of B6 was 2-fold lower (upregulation) than the gene expression of $\mathrm{C} 3 \mathrm{H}$ and $\mathrm{B} 6-\mathrm{Chr} 2^{\mathrm{C} 3 \mathrm{H}}$ strains based on signal value, and existed on chromosome 2. IPA was used to cluster the genes for possible biological pathways and to explore the inter-relationships between network genes with particular patterns.

\section{RT-PCR and Quantitative Real-Time PCR analysis}

In order to verify the microarray data, two genes from different categories and the housekeeping gene ( $\beta$-actin) (positive control) were analyzed by reverse transcription polymerase chain reaction (RT-PCR) and quantitative Real-Time PCR analyses.

For PCR analysis, the submandibular glands were dissected from 3 mice from each strain at 49 days of age. Total RNA was individually extracted from the submandibular glands using an RNeasy Mini kit (QIAGEN, Valenca, 
Table 1 Primer used by RT-PCR and Real-Time PCR

\begin{tabular}{|c|c|c|c|}
\hline Gene & Sequence & exon position & size \\
\hline \multicolumn{4}{|l|}{ RT-PCR } \\
\hline \multirow{2}{*}{ Calpain3 } & Fowerd : 5'-AGGTGGGAACACCACAGAAGCCA-3' & exson5 & \multirow{2}{*}{675} \\
\hline & Reverse: 5'-CGGTCCTTGCGCCGGTTCTT-3' & exson10 & \\
\hline \multirow{2}{*}{ Transmenbrane87a } & Fowerd : 5'-GCACTTCCGGCCTTGCTGGA-3' & exson19 & \multirow{2}{*}{335} \\
\hline & Reverse: 5'-ACATGTAGCTTGCAAAAACAGCCGT-3' & exson 20 & \\
\hline \multicolumn{4}{|l|}{ Real-Time PCR } \\
\hline \multirow[t]{2}{*}{ Calpain3 } & Fowerd : 5'-ACACAGACCAGGAAAGTGGAG-3' & exon14 & \multirow{2}{*}{127} \\
\hline & Reverse: 5'-CTTGTGTTTGTTCACCACTG-3' & exon15 & \\
\hline \multirow[t]{2}{*}{ Transmembrane $87 \mathrm{a}$} & Fowerd : 5'-GCACTCGTGTATGTGCTGT-3' & exon16 & \multirow{2}{*}{122} \\
\hline & Reverse: 5'-CCACTTCATGCAAGAATACC-3' & exon18 & \\
\hline
\end{tabular}

CA), in accordance with the manufacturer's instructions. cDNA was synthesized from this total RNA using PrimeScript II 1st strand cDNA Synthesis kit (Takara, Tokyo, Japan).

RT-PCR was carried out using a Gene Amp PCR System 9700 (Applied Biosystems, Foster City CA). Primer sets are listed in Table 1. PCR products were electrophoresed on $4 \%$ agarose gels.

Real-Time PCR was carried out using DNA Engine Opticon (BioRad, Hercules, CA) with a DYNAMO SYBR Green qPCR Kit (Finnzymes, Espoo, Finland). The PCR protocol entailed an initial incubation at $95^{\circ} \mathrm{C}$ for $5 \mathrm{~min}$, followed by 40 cycles of $94^{\circ} \mathrm{C}$ for $15 \mathrm{~s}, 56^{\circ} \mathrm{C}$ for $30 \mathrm{~s}$, and $72^{\circ} \mathrm{C}$ for $30 \mathrm{~s}$. Primer sets are listed in Table1. Gene expression levels in Real-Time PCR were calculated using the $\Delta \Delta \mathrm{Ct}$ method with normalization against-actin (13)

\section{Measurement of total protein in saliva}

Stimulated saliva was collected from three mice of each strain at 49 days of age. Mice were weighed and anesthetized with an intraperitoneal injection of $50 \mathrm{mg} / \mathrm{kg}$ sodium pentobarbital. These mice were then injected intraperitoneally with pilocarpin $(10 \mathrm{mg} / \mathrm{kg})$ to harvest stimulated saliva. Five minutes after injection of pilocarpin, secreted saliva was collected for 30 min using a micropipette. Protein concentration in saliva was measured using a Bio-rad Protein Assay Kit (BioRad Japan, Tokyo, Japan) based on the method of Bradford (14). Total salivary protein was determined using a standard curve prepared using albumin as a reference.

Statistical analysis of Real-Time PCR and salivary protein data

Statistical analysis of variations in Real-Time PCR and salivary protein were performed by Tukey's test as a post-hoc comparison of each group after ANOVA for multiple comparisons.

\section{Results}

Gene expression in submandibular glands

We initially compared the gene expression patterns in the 3 mouse strains. In a total of 24,896 genes on the genechip array, 592 genes were classified as present in C3H, B6-Chr2 ${ }^{\mathrm{C} 3 \mathrm{H}}$ and absent in $\mathrm{B} 6$. Of these 592 genes, there were 517 with a signal intensity of more than 100 and 127 genes with signal intensity of more than 300 , and 12 of these were located on chromosome 2 (Table2). On the other hand, 15,894 genes were classified as present calls in the 3 mouse strains. Of these, 72 showed that gene expression that was 2-fold lower (upregulation) in $\mathrm{B} 6$ than in $\mathrm{C} 3 \mathrm{H}$ and $\mathrm{B} 6-\mathrm{Chr} 2^{\mathrm{C} 3 \mathrm{H}}$, and 14 of these were located on chromosome 2 (Table 3$)$.

\section{Ingenuity Pathways Analysis}

In order to analyze the role of differences in gene expression using Expression Console Software, two categories were analyzed by IPA. The 12 genes probe sets derived from category 1 were related to Cell Cycle, Reproductive System Development and Function, Connective Tissue Development and Function in associated network functions. The 14 genes probe sets derived from category 2 were related to Tissue Morphology, Cell Death and Survival, Connective Tissue Development and Function in associated network functions (Table4).

\section{RT-PCR and Quantitative Real-Time PCR}

RT-PCR and quantitative Real-Time PCR analysis were used to confirm the microarray data, and we analyzed data 
Table 2 Genes of category 1

\begin{tabular}{|c|c|c|c|c|}
\hline Gene Symbol & $\mathrm{C} 3 \mathrm{H}$ signal value & B6-Chr2 ${ }^{\mathrm{C} 3 \mathrm{H}}$ signal value & Public ID & Probe Set ID \\
\hline$\overline{\text { Capn3 }}$ & 983 & 1386 & AF127766 & 1426043_a_at \\
\hline Galnt3 & 800 & 825 & BC003765 & 1427749_at \\
\hline Tnkslbpl & 689 & 644 & BQ031120 & 1427051_at \\
\hline Pak6 & 684 & 603 & BB818370 & 1455200_at \\
\hline$A W 555355$ & 612 & 408 & AW555355 & 1444273_at \\
\hline Pigu & 570 & 701 & AW538039 & 1427928_s_at \\
\hline Pofut1 & 511 & 380 & BE946126 & 1443881_at \\
\hline$P b x 3$ & 490 & 493 & NM_016768 & 1421193_a_at \\
\hline Serinc3 & 471 & 616 & NM_012032 & 1417816_s_at \\
\hline Ртрса & 391 & 677 & AK004549 & 1424661_at \\
\hline Usp8 & 365 & 545 & AB045709 & 1422883_at \\
\hline Harbil & 351 & 447 & BM231455 & 1423794_at \\
\hline
\end{tabular}

Table 3 Genes of category 2

\begin{tabular}{|c|c|c|c|c|}
\hline Gene Symbol & $\mathrm{C} 3 \mathrm{H} / \mathrm{B} 6$ & $\mathrm{~B} 6-\mathrm{Chr} 2^{\mathrm{C} 3 \mathrm{H}} / \mathrm{B} 6$ & Public ID & Probe Set ID \\
\hline Tmem87a & 10 & 9 & $\mathrm{BC} 027354$ & 1424454_at \\
\hline Rbm45 & 5 & 6 & BB821609 & 1437904_at \\
\hline Elf5 & 4 & 4 & BC012424 & 1419556_at \\
\hline Gchfr & 4 & 3 & BB610454 & 1435750_at \\
\hline Ubrl & 3 & 2 & BG075178 & 1458033_at \\
\hline Slc $25 a 12$ & 3 & 5 & BB526231 & 1444489_at \\
\hline 1700007K13Rik & 3 & 2 & AK005731 & 1428705_at \\
\hline Sord & 3 & 3 & AV253518 & 1438183_x_at \\
\hline Dhtkd1 & 3 & 3 & BB667395 & 1457027_at \\
\hline Fahd $2 a$ & 2 & 2 & $\mathrm{BI} 872590$ & 1431189_a_at \\
\hline--- & 2 & 2 & AI746468 & 1439960_at \\
\hline Zfp106 & 2 & 3 & $\mathrm{BC} 025424$ & 1425098_at \\
\hline --- & 2 & 3 & AW495875 & 1435129_at \\
\hline Dtwdl & 2 & 2 & BC020149 & 1424697_at \\
\hline
\end{tabular}

Table4 Identification in molecular networks generated in category 1 and 2 by IPA

\begin{tabular}{|c|c|c|}
\hline Top Functions ${ }^{\mathrm{a}}$ & Focus Molecules $^{\mathrm{b}}$ & Molecules in Network ${ }^{c}$ \\
\hline \multicolumn{3}{|l|}{ Category 1} \\
\hline $\begin{array}{l}\text { Cell Cycle, Reproductive System } \\
\text { Development and Function, Connective } \\
\text { Tissue Development and Function }\end{array}$ & 11 & $\begin{array}{l}\text { HABIl, CAPN3, GALNT3, PAK6, PBX3, PIGU, PMPCA, } \\
\text { POFUT1, SERINC3, TNKS1BP1, USP8 }\end{array}$ \\
\hline \multicolumn{3}{|l|}{ Category 2} \\
\hline $\begin{array}{l}\text { Tissue Morphology, Cell Death and Survial, } \\
\text { Connective Tissue Development } \\
\text { and Function }\end{array}$ & 12 & $\begin{array}{l}\text { DHTKD1, DTWD1, ELF5,FAHD2A, GCHFR, RBM45, } \\
\text { RPUSD2, SLC25A12, SORD, TMEM87A, UBR1,ZFP106 }\end{array}$ \\
\hline
\end{tabular}

a Transcripts with significantly different expression (focus genes) were analyzed by IPA for generation networks and assessment of function.

b Number of focus genes in the network.

c Assignment of function to a network is based on literature stored in the IPA Knowledge Base. 


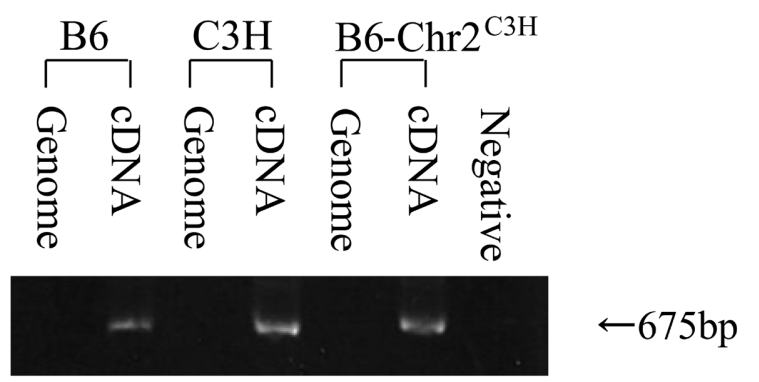

Figure 1-A. RT-PCR of Calpain3.

The PCR product of 3 strains were comfirmed by template from cDNA as positive band around 675bp. No band was detected by template form genome 3 strains and DW as negative control around same position.

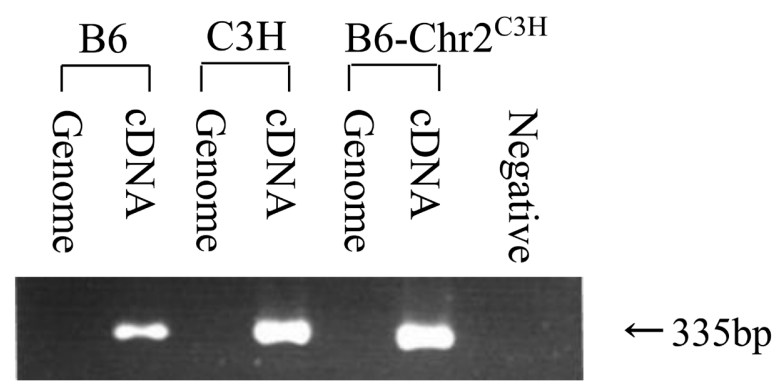

Figure 1-B. RT-PCR of Tmem87a.

The PCR product of 3 strains were comfirmed by template from cDNA as positive band around 335bp. No band was detected by template form genome 3 strains and DW as negative control around same position.

from 2 genes, Capn 3 and Tmem87A, which showed the largest differences in expression among $\mathrm{B} 6$, and $\mathrm{C} 3 \mathrm{H}$ and $\mathrm{B} 6-\mathrm{Chr} 2^{\mathrm{C} 3 \mathrm{H}}$. RT-PCR assays showed high density for the cDNA products of $\mathrm{C} 3 \mathrm{H}$ and $\mathrm{B} 6-\mathrm{Chr} 2^{\mathrm{C} 3 \mathrm{H}}$ in $\mathrm{Capn} 3$ and Tmem87A (Figs.1-A and 1-B). These results were correlated with the results of the microarray assays for two samples, and quantitative Real-Time PCR data confirmed the differences in microarray data with regard to the expression of Capn 3 and Tmem87A. The relative abundance in $\mathrm{B} 6$ after normalization against $\beta$-actin was significantly lower than in $\mathrm{B} 6-\mathrm{Chr} 2^{\mathrm{C} 3 \mathrm{H}}$ and $\mathrm{C} 3 \mathrm{H}$ (Figs.2-A and $2-\mathrm{B}$ ).

\section{Salivary protein}

Table 5 summarizes the relative differences of total saliva volume, protein concentration and total protein volume in the 3 strains. The largest saliva volume was seen in $\mathrm{C} 3 \mathrm{H}$ at $220 \mu \mathrm{l}$, followed by B6-Chr2 ${ }^{\mathrm{C} 3 \mathrm{H}}$ at $213 \mu \mathrm{l}$ and $\mathrm{B} 6$ at $81.6 \mu \mathrm{l}$. Total saliva volume in $\mathrm{B}^{-}{ }^{-} \mathrm{Chr} 2^{\mathrm{C} 3 \mathrm{H}}$ and $\mathrm{C} 3 \mathrm{H}$ was signifi-
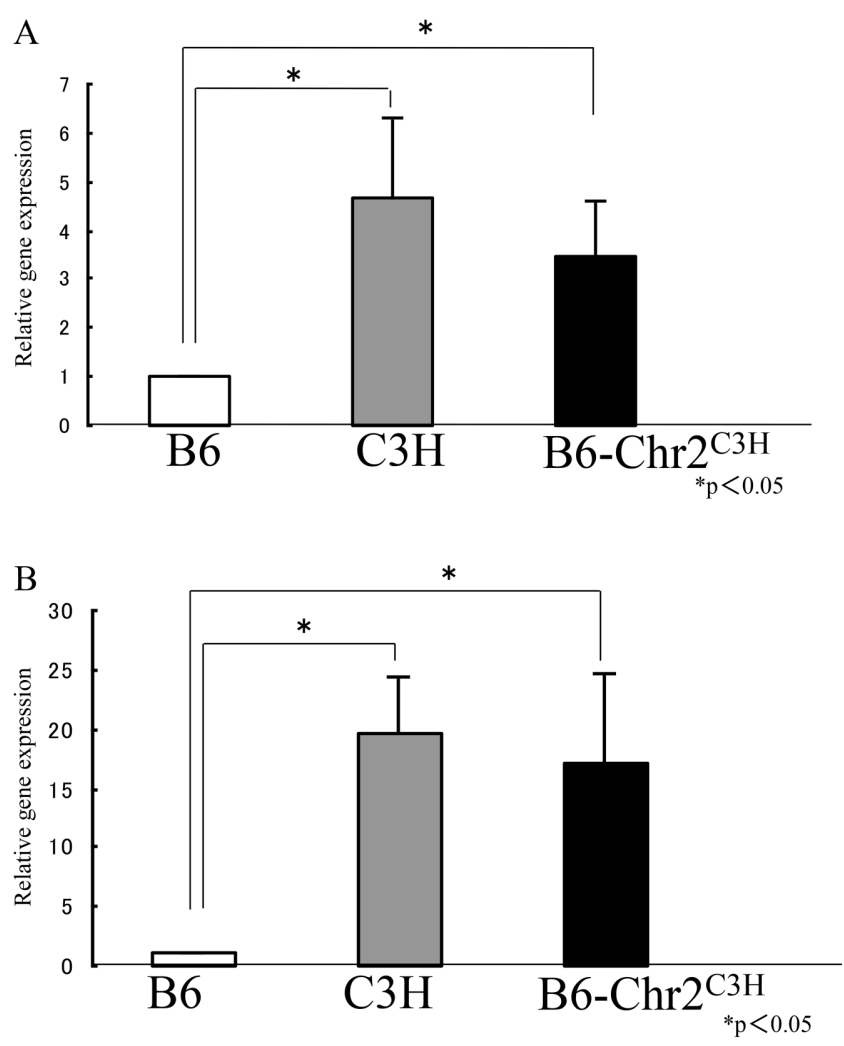

Figure 2-A. Real-Time PCR of Calpain3.

Figure 2-B. Real-Time PCR of Tmem87a.

Each bar corresponds to the mean $( \pm \mathrm{SD})$ for each strain of mouse.

cantly higher than in B6. Protein concentrations in $\mathrm{C} 3 \mathrm{H}$, $\mathrm{B} 6-\mathrm{Chr} 2^{\mathrm{C} 3 \mathrm{H}}$ and $\mathrm{B} 6$ were $0.210 \mu \mathrm{g} / \mathrm{ml}, 0.177 \mu \mathrm{g} / \mathrm{ml}$ and $0.217 \mu \mathrm{g} / \mathrm{ml}$, respectively. Protein concentration in $\mathrm{B} 6-\mathrm{Chr} 2^{\mathrm{C} 3 \mathrm{H}}$ was significantly lower than in $\mathrm{B} 6$ and $\mathrm{C} 3 \mathrm{H}$. Total protein volume in $\mathrm{C} 3 \mathrm{H}, \mathrm{B} 6-\mathrm{Chr} 2^{\mathrm{C} 3 \mathrm{H}}$ and $\mathrm{B} 6$ was $0.0460 \mathrm{ng}, 0.0377 \mathrm{ng}$ and $0.0177 \mathrm{ng}$, respectively, and total protein volume in $\mathrm{B}^{-}{ }^{-} \mathrm{Chr} 2^{\mathrm{C} 3 \mathrm{H}}$ and $\mathrm{C} 3 \mathrm{H}$ was significantly lower than in B6.

\section{Discussion}

The relationship between host genetic background and progress of dental caries is poorly understood. In this study, we evaluated the role of genetic factors on chromosome 2 in order to clarify the factors influencing dental caries susceptibility. Our previous study showed that host genetic factors on chromosome 2 influence caries susceptibility (7-9). Thus, we established $\mathrm{B} 6-\mathrm{Chr} 2^{\mathrm{C} 3 \mathrm{H}}$, in which chromosome 2 derived from $\mathrm{B} 6$ was replaced with chromosome 2 derived from $\mathrm{C} 3 \mathrm{H}(10)$. This $\mathrm{B} 6-\mathrm{Chr}^{\mathrm{C} 3 \mathrm{H}}$ strain showed 
Table 5 Saliva protein concentration, amount of saliva, total saliva protein in 3 strains

\begin{tabular}{|c|c|c|c|}
\hline Strain & $\begin{array}{c}\text { Protein concentration } \\
(\mu \mathrm{g} / \mathrm{ml})\end{array}$ & $\begin{array}{c}\text { Total saliva volume } \\
\left(\begin{array}{ll}\mu \mathrm{I})\end{array}\right.\end{array}$ & $\begin{array}{l}\text { Total protein } \\
\text { volume }(\mu \mathrm{g})\end{array}$ \\
\hline $\begin{array}{c}\text { B6 } \\
(n=3)\end{array}$ & $0.217( \pm 0.0093)$ & $81.6( \pm 14.1)$ & $0.0177( \pm 0.0028)$ \\
\hline $\begin{array}{r}\text { C3H } \\
(n=3)\end{array}$ & $0.209( \pm 0.0064)$ & $* 220( \pm 35.6)-*$ & * $0.0460( \pm 0.0068)$ \\
\hline $\begin{array}{c}\text { B6-Chr2 } \\
(\mathrm{n}=3)\end{array}$ & $0.177( \pm 0.0038)$ & $213( \pm 26.2)$ & $0.0377( \pm 0.0041)$ \\
\hline
\end{tabular}

Data are expressed as the mean $\pm \mathrm{SD}$.

significantly lower caries scores than B6, and showed no significant differences with $\mathrm{C} 3 \mathrm{H}$. In addition, the amount of saliva in the $\mathrm{B} 6-\mathrm{Chr} 2^{\mathrm{C} 3 \mathrm{H}}$ strain was greater than that in $\mathrm{B} 6$ strain and lower than that in $\mathrm{C} 3 \mathrm{H}(11)$.

We suspected that the differences in saliva volume may influence differences in caries susceptibility among the 3 mouse strains. Thus, we believed that differences in saliva volume affect gene expression in the submandibular gland, and that gene expression in the submandibular gland led to differences in caries susceptibility. On microarray analysis, we focused on the Calpain3 (Capn3) and transmembrane protein $87 \mathrm{~A}$ genes (Tmem87A), which showed significantly different expression. Capn 3 is a $\mathrm{Ca}^{2+}$-activated cysteine protease and we believe that Capn3 is related to caries susceptibility because salivary fluid secretion is $\mathrm{Ca}^{2+}$-dependent (15). However, there have been no reports on Capn3 expression in the salivary glands. The molecular identity of Tmem87A is unknown. However, Young et al. (16) reported that transmembrane protein $16 \mathrm{~A}$ (Tmem16A, which is also known as anoctamin 1 (ANO1)) is a bona fide calcium $\left(\mathrm{Ca}^{2+}\right)$-activated chloride $\left(\mathrm{Cl}^{-}\right)$ channel that is activated by intracellular $\mathrm{Ca}^{2+}$ and $\mathrm{Ca}^{2+}$ -mobilizing stimuli. As Tmem87A and Tmem16A are transmembrane proteins that have similar molecular structures, we believe that $T m e m 87 \mathrm{~A}$ plays a similar role as Tmem16A. Thus, Capn3 and Tmem87A are related to quantity of secreted saliva.

Our data suggest that Tmem87A and Capn3 are genetic factors involved in the differences in dental caries sensitivity among the 3 mouse strains. Culp at el. show that caries score is significantly increased in aquaporin5 (Aqp5)-deficient mice (17), and Ma et al. reported that $A q p 5$ affects salivary fluid secretion in the salivary gland $(18,19)$. However, differences in $A q p 5$ gene expression were not observed among the 3 mouse strains. We believe that there are multiple genetic factors related to caries. In addition, $A q p 5$ is located on chromosome 15 in mice. Therefore, caries susceptibility in $\mathrm{B} 6-\mathrm{Chr} 2^{\mathrm{C} 3 \mathrm{H}}$, in which chromosome 2 is replaced, does not have a direct influence.

On IPA, differences among $\mathrm{B} 6$, and $\mathrm{C} 3 \mathrm{H}$ and $\mathrm{B} 6-\mathrm{Chr} 2^{\mathrm{C} 3 \mathrm{H}}$ were related to connective tissue development and function of the submandibular gland. Thus, the number and structure of the acinus and ducts in the submandibular glands differ among the 3 strains.

Host factors for dental caries susceptibility are influenced by salivary parameters such as buffer capacity, cariogenic bacteria counts, $\mathrm{pH}$, salivary secretion, total saliva volume and total protein content (20). Orino et al. reported that the salivary flow volume in $\mathrm{B} 6-\mathrm{Chr} 2^{\mathrm{C} 3 \mathrm{H}}$ was significantly lower than in $\mathrm{C} 3 \mathrm{H}$, and significantly higher than in B6 (10). This study showed similar results. Dental caries susceptibility may thus be related to total saliva concentration (21) and salivary components $(22,23)$. Therefore, because the proteins in saliva may affect caries sensitivity, we measured salivary protein concentration in the 3 mouse strains. Protein concentration of $\mathrm{B} 6-\mathrm{Chr} 2^{\mathrm{C} 3 \mathrm{H}}$ was significantly lower than in $\mathrm{B} 6$ and $\mathrm{C} 3 \mathrm{H}$. However, the total protein volume in ${ }^{\mathrm{B} 6}{ }^{-} \mathrm{Chr} 2^{\mathrm{C} 3 \mathrm{H}}$ and $\mathrm{C} 3 \mathrm{H}$ was significantly lower than in $\mathrm{B} 6$. Furthermore, when saliva from the 3 mouse strains was placed in medium with S. mutans, the colony counts did not significantly differ (unpublished data). Our data suggest that salivary proteins do not participate in the differences in caries susceptibility in the 3 mouse strains.

In conclusion, our results suggest that Tmem $87 A$ and Capn 3 on chromosome 2 play a role in caries susceptibility. Moreover, salivary protein does not affect caries susceptibil- 
ity in the 3 strains. This suggests that differences in caries sensitivity between $\mathrm{B} 6, \mathrm{C} 3 \mathrm{H}$ and $\mathrm{B} 6-\mathrm{Chr}{ }^{\mathrm{C} 3 \mathrm{H}}$ are based on differences in water secretion and transportation in the salivary gland.

\section{Acknowledgments}

We are grateful to Prof. T.Maeda, Department of Pediatric Dentistry, Nihon University of Dentistry at Matsudo. We also thank the members of the Department of Pediatric Dentistry for helpful discussions. This study was funded in part by a Grant for the Support of Projects for Strategic Research at Private Universities by the Ministry of Education, Culture, Sports, Science and Technology (MEXT), 2008-2112.

\section{References}

1. Lehner T, Lamb JR, Welsh KL, Batchelor RJ: Association between HLA-DR antigens and helper cell activity in the control of dental caries. Nature, 292: 770-772, 1981.

2. Yoshida N, Yoshida K, Nakamura H, Iwaku M, Ozawa H: Immunohistochemical localization of HLA-DR-positive cells in unerupted and erupted normal and carious human teeth. J Dent Res, 75: 1585-1589, 1996.

3. Borass JC, Messer LB, Till MJ: A genetic contribution to dental caries, occlusion, and morphology as demonstrated by twins reared apart. J Dent Res, 67: 1150-1155, 1988.

4. Kurihara Y, Naito T, Obayashi K, Kurihara Y, Moriwaki K: Caries susceptibility in inbred mouse strains and inheritance patterns in F1 and backcross (N2) progeny from strains with high and low caries susceptibility. Caries Res, 25: 341-346, 1991.

5. Maeda T, Ogiwara K, Kurihara Y: Study on the inheritance patterns of caries susceptibility in Inbred Mice. Jpn J Ped Dent, 30: 618-623, 1992.

6. Obayashi K: Caries susceptibility of Balb/c mice to caries induction by Streptococcus serotype c, d, g strains. Jpn J Ped Dent, 22: 87-95, 1984.

7. Nariyama M, Shimizu K, Uematsu T, Maeda T: Identification of chromosomes associated with dental caries susceptibility using quantitative trait locus analysis in mice. Caries Res, 38 : 79-84, 2004.

8. Suzuki N, Kurihara Y, Kurihara Y: Dental caries susceptibility in mice is closely linked to the $\mathrm{H}-2$ region on chromosome 17.
Caries Res, 32: 262-265, 1998.

9. Uematsu T, Nariyama M, Shimizu K, Maeda T: Mapping of effected gene (s) to dental caries susceptibility on mouse chromosome 2. Ped Dent J, 13: 75-81, 2003.

10. Nomi M, Shimizu K: Establishment of consomic mice to clarify host susceptibility to caries. Ped Dent J, 19: 74-81, 2009

11. Orino D, Shimizu K: Reduced dental caries susceptibility in chromosome 2-substituted consomic mice. Int J Oral-Med Sci, 9: 234-240. 2011.

12. Ingenuity Systems, www.ingenuity.com, Redwood City, CA.

13. Livak KJ, Schmittgen TD: Analysis of Relative Gene Expression Data Using Real-Time Quantitative PCR and the $2^{-\Delta \Delta \mathrm{Ct}}$ Method. Methods, 25: 402-408, 2001.

14. Bradford M. M: A Rapid and Sensitive Method for the Quantitation of Microgram Quantities of Protein Utilizing the Principle of Protein-Dye Binding. Anal Biochem, 72: 248-254, 1976.

15. Qi B, Narita T, Satoh K, Guo MY, Katsumata-Kato O, Murakami M: Characteristics of neurokinin A-induced salivary fluid secretion in perfused rat submandibular gland. Arch Oral Biol, 55: 737-744, 2010.

16. Young YD, Hawon Cho, Jae Yeon Koo, Min Ho Tak, Yeongyo Cho, Won-Sik Shim: TMEM16A confers receptor-activated calcium-dependent chloride conductance. Nature, 455: 12101216, 2008.

17. Culp DJ, Quivey RQ, Bowen WH, Fallon MA, Pearson SK, Faustoferri R: A Mouse Caries Model and Evaluation of Aqp5-/-Knockout Mice. Caries Res, 39: 448-454, 2005.

18. Ma T, Song Y, Gillespie A, Carlson EJ, Epstein CJ, Verkman AS: Defective Secretion of Saliva in Transgenic Mice Lacking Aquaporin-5 Water Channels. J Biol Chem, 274: 20071-20074, 1999.

19. Tradtrantip L, Tajima M, Li L, Verkman AS: Aquaporin water channels in transepithelial fuid transport. J Med Invest, 56: $179-184,2009$.

20. Leone CW, Oppenheim FG: Physical and chemical aspects of saliva as indicators of risk for dental caries in humans. J Dent Educ, 65: 1054-1062, 2001.

21. Masakuma K, Inaba R, Iwata H: Salivary calucium and total protein in relation to dental caries. Nihon Eiseigaku Zasshi, 50: 886-892, 1995.

22. Scannapieco FA: Saliva-bacterium interactions in oral microbial ecology. Crit Rev Oral Biol Med, 5: 203-248, 1994.

23. Lenander-Lumikari M, Lomaranta V: Saliva and Dental Caries. Adv Dent Res, 14: 40-47, 2000. 